\title{
The Court, the Legislature and the Co-Construction of a Status of Social Integration
}

\author{
Stephen Coutts*
}

\section{Introduction}

25 years after its introduction, Union citizenship has demonstrated a remarkable capacity for dynamism. As a legal institution its history has been marked by an almost constant development prompted first by the Court and later developed by the legislature. Originally considered a mere cipher, ${ }^{1}$ Union citizenship constituted the vehicle by which rights previously the preserve of the economically active were extended to the non-economically active. In this way a novel transnational membership status has been progressively developed. As noted by the Kostakopoulou, its development is best understood as a constructive process, with Union citizenship evolving through the contributions of different actors at different stages of its development. ${ }^{2}$ The purpose of this contribution is to assess the respective roles of the Court and the legislature in the development of Union citizenship. It will be argued that both institutions have contributed in a largely complementary fashion to the development of this institution and to its current shape. Particular emphasis is placed on the development of Union citizenship as a transnational status of social integration.

An important consideration here is the debate that was triggered by the Dano line of caselaw regarding the appropriate interpretative role of the Court of Justice in this field, which is characterised by an unsettled hierarchy of norms

* School of Law, University College Cork.

1 Kostakopoulou, D. (2005). Ideas, Norms and European Citizenship: Explaining Institutional Change. Modern Law Review 68 (2), pp. 233-267, 234-235. For a prescient account of an 'incipient' European citizenship, developed from free movement of persons provisions in the early years of the internal market see Plender, R. (1976). An Incipient Form of European Citizenship. In: Jacobs, ed., European Law and the Individual. Amsterdam: North-Holland Publishing Company.

2 Ibid and Kostakopoulou, D. (2013). Co-Creating European Union Citizenship: Institutional Process and Crescive Norms. Cambridge Yearbook of European Legal Studies 15, pp. 255-282. 
between primary and secondary law. This contribution is related to that debate and the analyses of van den Brink, ${ }^{3}$ Mortiz and Carter ${ }^{4}$ and Muir ${ }^{5}$ are relied upon here. ${ }^{6}$ However, the focus of this chapter is not so much on the interpretive techniques of the Court of Justice, its activism or otherwise, and whether or not this is appropriate in the context of Union citizenship but instead on the development of Union citizenship as an institution of transnational and supranational membership, the respective contributions of the legislator and the Court to this construction and the interaction between their respective contributions. The conclusion is that both have contributed to giving constitutional shape to this institution in a broadly collaborative and symbiotic manner. However, before engaging in a discussion of the respective contributions of the Court and the legislator it is necessary to clarify the constitutional context. The next section will therefore assess the roles attributed to these actors by the relevant Treaty provisions, noting in particular the unusual position of secondary law and hence the legislature in this scheme. Section II will assess the role of the legislator and the contribution made in the form of Directive 2004/38/EC to the development of Union citizenship as a transnational status of integration. Section III will address the manner in which the Court of Justice has engaged with and utilised this directive in its jurisprudence and ongoing development of the institution of Union citizenship. A final section will draw some conclusions.

3 See Van den Brink, M. (2019). Justice, Legitimacy and the Authority of Legislation within the European Union. Modern Law Review 82 (2), pp. 293-318.

4 Moritz Jesse and Daniel Carter in this volume. See also an analysis of this question in Níc Shuibhne, N. (2015). Limits Rising, Duties Ascending: The Changing Legal Shape of Union Citizenship. Common Market Law Review 52 (4), pp. 889-937, and Spaventa, E. (2017). Earned Citizenship: Understanding Union Citizenship through its Scope. In: Kochenov, ed., EU Citizenship and Federalism: The Role of Rights. Cambridge: Cambridge University Press.

5 Elise Muir in this volume.

6 The pieces relied upon here relate to the question of interpretation and the relationship between the legislature and the Court in the field of Union citizenship. This debate was triggered by the Court's jurisprudence in the field of access to social benefits, especially Court of Justice, judgment of 11 November 2014, case C-333/13, Dano and related judgments. This restrictive turn in the case law was not uncriticised, including in the new, more deferential role adopted by the Court of Justice. See for example Spaventa, E. (2017). Earned Citizenship: Understanding Union Citizenship through its Scope, cit., and O'Brien, C. (2017). The ECJ Sacrifices EU Citizenship in Vain: Commission v United Kingdom. Common Market Law Review 54 (1), pp. 209-243. See also the contributions in Thym, D., ed. (2017). Questioning EU Citizenship:Judges and the Limits of Free Movement and Solidarity in the EU. Oxford/Portland: Hart Publishing, for a discussion of this development. 


\section{The Constitutional Context and the Roles of the Court and the Legislature}

Before evaluating any contribution of the Court and legislature to the construction of Union citizenship it is necessary to first assess the constitutional context and legal framework for the establishment and elaboration of this institution. Union citizenship is an institution provided for and established by primary law, a point that has been reemphasised in the line of Article 20 TFEU judgments, starting with Rottmann ${ }^{7}$ and most recently reaffirmed in Tjebbes. ${ }^{8}$ Article 20 TFEU provides quite simply that 'Union citizenship is hereby established', performing an important constitutional speech act ${ }^{9}$ and one that has had important implications for the nationals of Member States, who now enjoy a complementary set of membership rights in other Member States. Some of these rights are then articulated in Article $21 \mathrm{TFEU}$, most importantly the rights to free movement and residence. A number of aspects of Articles 20 and 21 TFEU have implications for the roles of the Court and the legislature respectively.

It is worth noting the relatively open-textured nature of Article $20 \mathrm{TFEU}$ and to a lesser extent Article $21 \mathrm{TFEU}$. This is a feature of constitutional law and of Union law especially. Union citizenship is established and a set of rights are associated with it, especially free movement and residence. And yet the precise nature of Union citizenship is not entirely clear, especially how it relates to the broader composite constitution of the Union. ${ }^{10}$ For some it was simply a repackaging of internal market rights of free movement and establishment.11

7 Court of Justice, judgment of 2 March 2010, case C-135/o8, Janko Rottmann v. Freistaat Bayern.

8 Court of Justice, judgment of 12 March 2019, case C-221/17, Tjebbes and others. See paras. $3^{0-31}$ and $44 \mathrm{ff}$ in which the Court lays down criteria against which any decision withdrawing Member State nationality must be assessed, thus underlining the fact that loss of nationality falls within the framework of Union law. It should be noted however that the judgment is deferential regarding the operation of nationality law and in particular the reasons for withdrawal, leading some to criticise the judgment. See Kochenov, D. (2019). The Tjebbes Fail. European Papers Forum, available at http://www.europeanpapers.eu/en/ europeanforum/the-tjebbes-fail.

9 As noted by Kostakopoulou 'EU citizenship is not the product of mimesis; it is an actor original creation'. See Kostakopoulou, D. (2013). Co-Creating European Union Citizenship, cit., 258 .

10 Besselink, L. (2007). A Composite European Constitution. Groningen: Europa Law Publishing.

11 See Kostakopoulou, D. (2007). European Citizenship: Writing the Future. European Law Jounal 13 (5), pp. 623-646, 624 speaking of the 'minimalist assessments' of Union citizenship made by scholars in its early years. 
Alternatively, it may have contained the seeds for a supranational fully-fledged federal citizenship, for all intents and purposes replacing national citizenship as the operative status of individuals. Or was it intended to be a transnational citizenship that somehow went beyond the market freedoms? There are some hints in the treaty provisions; Union citizenship's relationship with nationality was underlined as complementary, as noted by the shift in language to 'additional to'. The rights that were listed for Union citizenship were free movement and residence; the heritage of the internal market is hard to deny ${ }^{12}$ and indeed influenced profoundly the Court's early post-Maastricht jurisprudence, including adopting various internal market related assumptions into the operation of Union citizenship. ${ }^{13}$ However, as Kochenov and Plender point out, these assumptions and the general trajectory of Union citizenship as an outgrowth of the internal market, were never dictated by the text of the Treaty itself, which left the precise contours of Union citizenship undefined and opened a space for its future construction. ${ }^{14}$

The fact that the status of Union citizenship and certain of its rights are found in primary law and hence enjoy a constitutional nature is relevant for the role of the Court of Justice. As put by Níc Shuibhne 'a constitutional court has a responsibility to protect and to further the objectives and values enshrined in "its" constitution - essentially to ensure that the rights and responsibilities that a constitution promises are realized ... and to discharge these tasks on behalf of and for the benefit of the constitutional subjects.' ${ }^{15}$ There is therefore a very legitimate role bestowed by the Treaties, understood as the Union's constitutional text, for the Court in giving expression to and shaping an institution established to integrate the individual as a key component in the Union's constitutional order. In light of its role as a constitutional court, the

12 Indeed, for many years academic debates centred precisely on its relationship with and difference from internal market freedoms. See for example Jacobs, F. (2007) Citizenship of the European Union - A Legal Analysis. European Law Jounal 13 (5), pp. 591-61o noting the movement towards replicating classic free movement rights (ie prohibitions on discrimination and on restrictions on movement) in a non-market context. The template of the internal market is impossible to deny here in the imagination of contributors. See also Wollenschläger, F. (2011). A New Fundamental Freedom beyond Market Integration: Union Citizenship and its Dynamics for Shifting the Economic Paradigm of European Integration. European Law Jounal 17 (1), pp. 1-34.

13 Kochenov, D., and Plender, R. (2012). EU Citizenship: From an Incipient Form to an Incipient Substance? European Law Review 37, pp. 369-396, 375 ff.

14 See ibid, also noting that it was not until the judgment in Rottmann that the Court fully acknowledged the implications of introducing citizenship status into the Treaties.

15 Níc Shuibhne, N. (2013). The Coherence of EU Free Movement Law: Constitutional Responsibility and the Court of Justice. Oxford: Oxford University Press, p. 8. 
Court has not only a role but a duty to contribute to the construction of Union citizenship and to give meaning to this institution in light of the broader constitutional context.

A further implication of the primary law nature of these rights is that the interventions of the Court, depending on their manner - enjoy a constraining capacity and anterior role vis-à-vis the legislature. This is perfectly logical and a necessary consequence of entrenching a status and set of rights in a constitution. ${ }^{16}$ The very purpose of entrenchment and having a constitutional status is to insulate that status from political pressures and ordinary legislative discretion. Having said that, we should be mindful of the other aspects of Níc Shuibhne's conception of the responsibilities of the Court as a constitutional court. In the passage cited above she also notes that a constitutional court has the right and duty to give expression to the values inherent in its constitution but also 'to respect the checks and limits built into it.'17 Likewise, the constitutional subject, while certainly including individual Union citizens also include the Member States, ${ }^{18}$ who it must be recalled, represent citizens of the Union in their capacity of nationals and the collective interests of those national communities.

16 Although we should be mindful of the particular problems of entrenchment in context of the European Union. On the one hand the Treaties contain provisions which would ordinarily not find themselves into a constitutional text. On the other the Treaties are particularly difficult to amend. This problem is compounded when the Court, employing a teleological interpretative technique, develops Treaty provisions in particular, politically important ways (see for example Court of Justice, judgment of 18 December 2007, case C341/05, Laval). The Court's interpretation of treaty provisions can constrain not only the Union legislature but Member State governments, a very present problem in the area of Union citizenship, as discussed in Schmidt, S.K. (2017). Extending Citizenship Rights and Losing it all: Brexit and the Perils of Over-Constitutionalisation. In Thym, ed., Questioning EU Citizenship: Judges and the Limits of Free Movement and Solidarity in the EU, cit. This danger of over-constitutionalisation or inappropriately entrenching particular political choices and ideologies leads to their removal from the realms of political contestation, generating difficulties of legitimacy for the Union. See for example in the context of the Eurocrisis Wilkinson, M.A. (2013). The Specter of Authoritarian Liberalism: Reflections on the Constitutional Crisis of the European Union. German Law Journal 14 (5). pp. 527-56o and Wilkinson, M.A. (2013). Political Constitutionalism and the European Union. Modern Law Review 76 (2), pp. 191-222. See also Přibáň, J. (2015). The Evolving Idea of Political Justice in the EU: From Substantive Deficits to the Systemic Contingency of European Society. In De Búrca, Kochenov and Williams, eds., Europe's Justice Deficit? Oxford/ Portland: Hart.

17 Ibid, 8.

18 For a discussion of the multi-faceted nature of the 'constitutional subject' see Rosenfeld, M. (2010). The Identity of the Constitutional Subject. Abingdon/New York: Routledge. 
This leads to the unusual position of the legislature in the field of Union citizenship law. On the one hand this is an entrenched status and rights, which should and has enjoyed protection from the intervention by the legislator through the interpretation and application of primary law by the Court of Justice. On the other hand, the precise manner of this entrenchment in the Treaties is ambiguous, with Article $20 \mathrm{TFEU}$ also providing that the rights associated with the status of Union citizenship 'shall be exercised in accordance with the conditions and the limits defined by the Treaties and by the measures adopted thereunder' while Article $21 \mathrm{TFEU}$ provides a legislative basis for secondary legislation to facilitate the rights contained in that provision..$^{19}$ Secondary legislation is given the unusual capacity of limiting and conditioning rights established by primary law. The legislature has a legitimate and constitutionally allocated role not only in in articulating detailed rules for its operation but in giving overall shape to Union citizenship. This unusual position of the legislature in Article 21 also introduces an ambiguity in the relationship between primary and secondary law, unsettling the classic hierarchy of laws. The caselaw has shifted from relying on the primary law nature of the rights created by Articles 20 and 21 TFEU - constraining the operation of secondary legislation and its application by Member States ${ }^{20}$ - to more recently respecting the special task allocated to the legislator in light Articles 20 and 21 TFEU by restricting itself to an analysis of secondary law and a more literal application of the conditions and limits it contains. ${ }^{21}$

The Treaties have therefore given a somewhat more prominent role to the legislature in shaping the institution of Union citizenship than might be expected and that might arise from a simple 'primary-secondary' law dichotomy. It also lays the normative foundation for a greater role for the legislator in designing and fashioning what is a constitutional status. On one view this gives the Member States the possibility of protecting or balancing their interests against those of mobile Union citizens. ${ }^{22}$ Although such a view establishes what might be a false opposition between the rights of mobile Union citizens and the interests of Member States. ${ }^{23}$ More importantly, the legislature has

\footnotetext{
19 Art 20 TFEU.

$20 \quad$ For an excellent analysis of this see Dougan, M. (2006). The Constitutional Dimension to the case law on Union Citizenship. European Law Review 31 (5), pp. 613-641.

21 See Jesse and Carter in this volume and especially Muir in this volume.

22 See paragraph 107 of Opinion of AG Wathelet delivered on 20 May 2014, case C-333/13, Dano, describing it as part of the legislature's intention to allow Member States to refuse to extend social assistance to non-national Union citizens.

23 More than anything they respond to the political imperatives faced by governments in Member States, in an environment hostile to EU migration. See for example the discussion of the so-called 'safeguard' offered the United Kingdom in the event of a vote to
} 
a key role in 'putting flesh on the bones' of Union citizenship, ${ }^{24}$ pouring real normative content into the shell provided by the Treaties, in designing what might be called the underlying philosophy of Union citizenship and ultimately shaping its contours. In this sense the legislature is a genuine 'co-interpreter' of the Treaties ${ }^{25}$ and enjoys a role alongside the Court as a co-constructor of this constitutional status. This importance attributed to the legislature has been affirmed by its approach, which has been to adopt an overarching framework law, providing not simply a set of rules guiding the operation of Union citizenship but containing within it a relatively coherent conception of Union citizenship as one based on transnational social integration. ${ }^{26}$ Directive 2004/ 38 /EC does more than merely elaborate technical rules and procedures in the fulfilment of some 'detail-filling' role subject to the parameters of a constitutionally determined status but gives shape to the underlying choices left open by the ambiguity inherent in Articles 20 and 21 TFEU on the nature of Union citizenship.

\section{The Legislature and Directive 2004/38/EC}

Directive 2004/38/EC was an important moment in the constitutional development of Union citizenship not only in codifying previous disparate pieces of legislation and detailing the rules surrounding the enjoyment of the various rights contained in the Directive but in contributing to the articulation of the constitutional form of Union citizenship as a status of transnational social integration. In adopting Directive 2004/38/EC, the Union legislature therefore played the role both of elaborating and reforming the law and of contributing in

remain in the European Union and the dangers of what this implies regarding the status of Union citizenship in Reynolds, S. (2017). (De)Constructing the Road to Brexit: Paving the Way to Further Limitations on Free Movement and Equal Treatment. In: Thym, ed., Questioning EU Citizenship:Judges and the Limits of Free Movement and Solidarity in the $E U$, cit.

24 To borrow a phrase from Síofra O'Leary when discussing the intervention of the Court in Court of Justice, judgment of 12 May 1998, case C-85/96, Maria Martínez Sala (see O'Leary, S. (1999). Putting flesh on the bones of European Union Citizenship. European Law Review 24 (1), pp. 68-79).

25 See Davies, G. (2018). Does the Court of Justice own the Treaties? Interpretative pluralism as a solution to over-constitutionalisation. European Law Journal 24 (6), pp. 358-375 referring primarily to the relationship between national courts and the Treaties.

26 For an account of Union citizenship as a status of social integration see Azoulai, L. (2010). La Citoyenneté Européenne, un Statut d'Intégration Sociale. In: Cohen-Jonathan and others, eds., Chemins d'Europe: Mélanges en l'honneur de Jean Paul Jacqué. Paris: Dalloz. 
a meaningful and constructive way to the constitutional construction of Union citizenship. Moreover Directive 2004/38/EC displays a clear engagement with the jurisprudence of the Court of Justice. In adopting Directive 2004/38/EC the legislature endorsed the nascent conceptualisation of Union citizenship developed by the Court in its foundational citizenship judgments, especially Martinez Sala ${ }^{27}$ and Grzelcyk ${ }^{28}$ by codifying the principles developed in those cases. Its contribution went beyond mere codification however but amounted to a genuine contribution to the shape of Union citizenship through crystallising the concept of a progressively enhanced citizenship status operating along the vector of social integration, as evidenced most strongly by the major innovation of the Directive, namely the status of permanent residence.

Firstly, Directive 2004/38/EC codified the law on Union citizenship. As identified by de Bruycker at the time, ${ }^{29}$ it did so in two ways. Firstly, the Directive incorporated and replaced most but not all of the diverse instruments that had heretofore regulated the position of the free movement of persons under the internal market and replaced it with a single instrument regulating the position of mobile Union citizens. Important gaps remained in its coverage, both regarding some aspects of the position of free movement of workers, which remained regulated by Regulation 1612/68/EEC ${ }^{30}$ (since replaced by Regulation $492 / 2011 / \mathrm{EU})^{31}$ and more crucially the position of the non-mobile or static Union citizen. ${ }^{32}$ It also reproduced within the status of Union citizenship some of the categories it was purporting to abolish through the imposition of variable conditions to different individuals depending on the basis of their stay in other Member States. Nonetheless, despite these deficiencies, the Directive 2004/38/EC remains a significant piece of codification providing an overarching framework for the free movement of persons and does so importantly under the rubric of the status of Union citizenship, performing an important symbolic shift from the language of workers, establishment and service provides

\footnotetext{
27 Martínez Sala, cit.

28 Court of Justice, judgment of 20 September 2001, case C-184/99, Grzelczyk.

29 De Bruycker, P. (2006). La Libre Circulation des Citoyens Europeens Entre Codification et Reforme. In: Carlier and Guild, eds., L'Avenir de la libre circulation des personnes dans l'UE/ The Future of Free Movemenet of Persons in the EU. Brussels: Bruylant.

30 Regulation 1612/68/EEC on freedom of movement for workers within the Community, OJ $L$ 257, 19.10.1968, p. 2-12.

31 Regulation 492/2011/EU on freedom of movement for workers within the Union (codification), OJ L 141, 27.5.2011, p. 1-12.

32 See Directive 2004/38/EC on the right of citizens of the Union and their family members to move and reside freely within the territory of the Member States, OJ L 158, 30.4.2004, p. $77-123, \operatorname{art} 3(1)$.
} 
to that of citizenship itself, indicating that these rights were to be enjoyed, at least potentially, by all citizens of the Union rather than simply market actors. The importance of this codification was acknowledged by the Court in Metock which found that the Directive aims to 'strengthen' and improve on the rights of free movement compared to the earlier directives it replaced. ${ }^{33}$ In Metock ' $[\mathrm{t}]$ he Court has ... given a distinctly positive and forward looking role to Directive 2004/38. The Directive is understood as a development on pre-existing legislation, giving expression to the primary citizenship rights. ${ }^{34}$

Secondly, in elaborating the Directive the legislator codified various elements of the early jurisprudence of the Court of Justice, which had (as is explored further below) begun to explore and define the contours of Union citizenship, building on ${ }^{35}$ but exceeding the limits of the internal market freedoms. Provisions on the exercise of the public policy exception were heavily revised from the by then out of date Directive $64 / 221 / \mathrm{EC}^{36}$ and, alongside updating considerably the procedural safeguards afforded individuals subject to expulsion and exclusion measures, incorporate large elements of the Court of Justice's jurisprudence. ${ }^{37}$ The engagement with the Court's jurisprudence is even more remarkable in relation to equal treatment in the field of social welfare where the legislature incorporated wholesale the somewhat ambiguous approach towards the relationship between equal treatment rights and residence adopted in Grzelczyk. ${ }^{38}$ As put by de Bruycker this incorporation was 'autant plus remarquable que cette decision absolument fondamentale s'inscrit dans une série d'arrêts audacieux, voire téméraires' ${ }^{39}$

33 Court of Justice, judgment of 25 July 2008, case C-127/o8, Metock v. Minister for Justince Equality and Law Reform, para. 59.

$34 \quad$ Muir in this volume at 173 .

35 For a critique of this approach linking post Maastricht Union citizenship with assumptions derived from the internal market see Kochenov, D., and Plender, R. (2012). EU Citizenship: Citizenship From an incipient form to an incipient substance? The discovery of the Treaty Text, cit.

36 Directive 64/221/EEC on the co-ordination of special measures concerning the movement and residence of foreign nationals which are justified on grounds of public policy, public security or public health, $O_{5} 6,4.4 .1964$, p. $850-857$.

37 See for example the proportionality test as elaborated in Court of Justice, judgment of 29 April 2004, joined cases C-482/o1 and C-493/o1 Georgios Ofanopoulos et al and Raffaele Oliveri v. Land Baden-Würtemberg and the definition of a threat to public policy as a 'genuine and sufficiently serious threat affecting one of the fundamental interests of society' articulated in in Court of Justice, judgment of 27 October 1977, case 30/77 Regina v. Pierre Bouchereau.

$38 \quad$ Grzelczyk, cit.

39 See De Bruycker, P. (2006). La Libre Circulation des Citoyens Europeens Entre Codification et Reforme, p. 40. 
This went beyond a mere codification of jurisprudential developments but involved an incorporation of the underlying philosophy articulated in the early jurisprudence of the Court regarding the position of mobile Union citizens and their relationship with the host Member State, a relationship that should be characterised by integration and solidarity. Despite its perhaps vague and somewhat contradictory nature, the Directive codified the rule of Grzelczyk, permitting Member States to withdraw a right of residence but not as an automatic consequence of recourse to social assistance. ${ }^{40}$ This reflected an acceptance of the embryonic philosophy of Union citizenship being articulated in the first wave of judgments of the Court of Justice. These set of cases were developing Union citizenship as a status which offered something to the noneconomically active Union citizens and imbued it with an underlying vocation to extend rights to the non-economically active Union citizen. This rested on a particular vision of the relationship between the mobile Union citizen and the host Member State which went beyond a market focused instrumentalism and instead focused on solidarity and inclusion. The beginnings of a transnational status of integration could be discerned. The important point here is that in its codification of these rules in Directive 2004/38/EC, the legislator responded to and endorsed this developing vision of Union citizenship.

Not only did it endorse the vision of Union citizenship advanced by the Court up to that point, in its contribution in Directive 2004/38/EC the legislature went further and brought its own contribution to that construction. Aside from simplified administrative burdens, ${ }^{41}$ the major innovation of the Directive was the introduction of the status of permanent residence. Acquired after 5 years of residence, those enjoying permanent residence are no longer subject to conditions on their residence nor to limitations on the right to equal treatment. On a doctrinal level is important for the security of residence it brings ${ }^{42}$ (although certainly not absolute, as was argued for by the Commission in the legislative process $)^{43}$ and for equal treatment. ${ }^{44}$ On a broader level regarding

\footnotetext{
$40 \quad$ Grzelczyk, cit., para. 43.

41 De Bruycker, P. (2006). La Libre Circulation des Citoyens Europeens Entre Codification et Reforme, p. 32.

42 See Directive 2004/38/EC on the right of citizens of the Union and their family members to move and reside freely within the territory of the Member States, OJ L 158, 30.4.2004, p. $77-123$, art 28(2).

43 See Proposal for a European Parliament and Council Directive on the right of citizens of the Union and their family members to move and reside freely within the territory of the Member States, OJ C 270E, 25.9.2001, p. 150-16o, art 26(2). Under the Commission's initial proposal absolute protection from expulsion would attach to permanent residence.

See Directive 2004/38/EC, cit., art 24(1).
} 
the nature of Union citizenship it is explicitly linked to the vocation for Union citizenship to be a 'genuine vehicle of integration' for the individual Union citizen into the society of the host Member State. As such it is a distinct contribution to the shaping of Union citizenship as a transnational status intended to facilitate the full inclusion of the individual into the society of the host Member State.

The Directive established a progressive status whereby rights were gradually acquired after periods of residence in the host Member State (under certain conditions) with three broad categories of citizens enjoying different levels of rights depending on their period of residence. The scheme established by the Directive is well known. What is worth stressing for present purposes is the general philosophy underpinning the Directive as one of gradual inclusion of the individual through the attribution of rights, acquired over time and one premised on integration, albeit an integration that is only manifested by time and place. ${ }^{45}$ The relationship between rights and integration has certainly been unsettled, with social integration shifting from a goal of rights attribution (rights in order to secure integration) to a precondition for rights. ${ }^{46}$ While this is an important development, what is emphasised here is the legislator's contribution to the shaping of Union citizenship not as a status of migration based on a particular activity - as existed before in the fragmented legislative landscape of the internal market - but as a fundamental status with the vocation of securing the inclusion and integration of the mobile Union citizen in the society of the host Member State, with this inclusion and integration to be secured and rewarded via a gradual acquisition of rights.

\section{The Role of the Court}

If the legislature has played a singularly important role Directive 2004/38/EC, which can rightly be termed an organic law, endorsing a particular conceptualisation of Union citizenship, namely as a transnational status of integration,

45 Somek, A. (2007). Solidarity Decomposed: Being and Time in European Citizenship. European Law Review 32 (6), pp. 787-818.

46 Secure residence rights, family reunification and broad equal treatment might be conceived of as facilitating integration. Since the 'reactionary turn' in Union citizenship law however, the security of residence rights and equal treatment in the field of social assistance have now become contingent on a particular form and level of social integration. See broadly Coutts, S. (2018). The Absence of Integration and the Responsibilisation of Union Citizenship. European Papers 3 (2), pp. 761-78o. 
what has been the role of the Court in the development of this institution? The Court's role has been threefold in its interaction with the Directive and by implication the legislature. Firstly, the Court has, taking seriously the primary law nature of the rights and status of Union citizenship, acted as the catalyst for the development of Union citizenship rights and shaping its basic principles. Secondly, it has played a key role in the interpretation of Directive 2004/ $38 / \mathrm{EC}$, not simply in giving expression to the will of the legislature as reflected in the text of the Directive but rather in interpreting the Directive in light of the broader nature of Union citizenship as a status of social integration. Finally, reflecting the key role of Directive 2004/38/EC in shaping the concept Union citizenship, the Court has also borrowed from the Directive, applying it 'by analogy' in areas not covered by the Directive itself.

\section{a) Catalyst for Constitutional Construction}

The original role of the Court was to act as a catalyst for the development of Union citizenship as a meaningful status and in providing initial guiding principles regarding its operation. This was originally performed in relation to the transnational dimension of Union citizenship as expressed in the rights contained in Article $21 \mathrm{TFEU}$. It has recently reprised this role in relation to the developing further the legal implications of the status of Union citizenship contained in Article 20 TFEU.

The initial introduction of Union citizenship in the Treaty of Maastricht carried with it few additional rights to those found in the free movement of persons under internal market law. The foundational judgments of Martínez Sala, ${ }^{47}$ Grzelczyk ${ }^{48}$ and Bidar ${ }^{49}$ significantly altered that situation and developed the status of Union citizenship into one of transnational social integration, a conception which, as described in the previous section, was endorsed and further developed by the legislature. The rights of free movement and residence were linked with a broader guarantee of non-discrimination, introducing the notion of equality - so central to the operation of citizenship as a concept - to the transnational context, providing the opportunity to force open national communities and in the words of Kostakopoulou render the boundaries between national communities more open and flexible..$^{50}$ Baumbast and

47 Martínez Sala, cit.

48 Grzelczyk, cit.

49 Court of Justice, judgment of 15 March 2005, case C-209/o3, The Queen (on the application of Dany Bidar) v. London Borough v. Ealing, Sec. of State for Education and Skills.

$5^{\circ}$ Kostakopoulou, D. (2007). European Citizenship: Writing the Future. European Law Jounal 13 (5), pp. 623-646, $634 \mathrm{ff}$. 
$R$ insisted on the primary law nature of the rights of free movement and residence and their direct effect, a move which allowed the Court to constrain the operation of the earlier secondary legislation and open it up to proportionality assessments. ${ }^{51}$ Grzelczyk found that Members States have accepted a certain degree of solidarity with mobile Union citizenship. In Bidar, ${ }^{52}$ this was combined with an emphasis on proportionality which itself was linked with the notion of integration; equal treatment should be guaranteed for individuals in accordance with their level of social integration in the society of the host Member State. Emerging from these cases is firstly the constitutional nature of Union citizenship and its rights and secondly the beginnings of a vision of Union citizenship based on transnational social integration, a vision which was taken and further developed by the legislature in Directive 2004/38/EC as described in the previous section.

More recently, the Court has also performed the role of catalyst in a further development of Union citizenship under Article 20 TFEU. In Rottmann, ${ }^{53}$ Ruiz Zambrano, ${ }^{54}$ Chavez-Vilchez ${ }^{55}$ and Tjebbes, ${ }^{56}$ the Court has, relying on the status of Union citizenship, developed the so-called 'genuine enjoyment test'. While clearly linked to the rights of free movement and residence contained

$5^{1}$ Court of Justice, judgment of 17 September 2002, case C-413/99, Baumbast and $R$ v. Secretary of State for the Home Department.

$5^{2}$ Bidar, cit.

53 Court of Justice, judgment of 2 March 2010, case C-135/o8, Janko Rottmann v. Freistaat Bayern. For a comment see Kochenov, D. (2010). Case C-135/o8, Janko Rottmann v. Freistaat Bayern, Judgment of the Court (Grand Chamber) of 2 March 2010. Common Market Law Review 47 (6), pp. 1831-1846.

54 Court of Justice, judgment of 8 March 2011, case C-34/og, Gerardo Ruiz Zambrano v. Office national de l'emploi (ONEm). For a comment see Níc Shuibhne, N. (2011). Seven Questions for Seven Paragraphs. European Law Review 36 (2), pp. 161-162. See also Azoulai, L. (2011). "Euro-Bonds" The Ruiz Zambrano judgment or the Real Invention of EU Citizenship. Perspectives on Federalism 3, pp. 33-39.

55 Court of Justice, judgment of 10 May 2017, case C-133/15, Chavez-Vilchez and Others $v$ Raad van bestuur van de Sociale verzekeringsbank and Others. For a comment see Staiano, F. (2018). Derivative Residence Rights for Parents of Union Citizen Children under Article 20 TfEu: Chavez-Vilchez. Common Market Law Review 55 (1), pp. 225-241.

56 Tjebbes, cit. For comments see Coutts, S. (2019). Bold and Thoughtful: the Court of Justice intervenes in Nationality Law, Case C-221/17 Tjebbes. European Law Blog, available at https://europeanlawblog.eu/2019/o3/25/bold-and-thoughtful-the-court-of-justiceintervenes-in-nationality-law-case-c-221-17-tjebbes; Van den Brink, M. (2019). Bold, but Without Justification? Tjebbes. European Papers 4 (1), pp. 409-415; Kochenov, D. (2019). The Tjebbes Fail, cit. and Platon, S. (2019). L'insoutenable légèreté de la citoyenneté de l'Union européenne: l'arrêt Tjebbes et la perte de nationalité pour les personnes résidant à l'étranger.Journal d'Actualités de Droit Européen, available at http://revue-jade.eu/article/view/2535. 
in Article 21 TFEU, it does provide a certain baseline of protection for Union citizens, especially non-mobile Union citizen minors. It also reflects a right to place associated with Union citizenship, where that place is the Union territory. ${ }^{57}$ Perhaps more significantly it carries within it significant potential for future development of Union citizenship. ${ }^{58}$

The Court has therefore played its legitimate constitutional role, affirming the constitutional nature of the status, elaborating and protecting basic principles and rights contained in the constitutional text and developing from them an underlying philosophy - of transnational social integration in the area of Article $21 \mathrm{TFEU}$ rights and of the right to a place in the field of Article 20 TFEU. At least in the case of Article 21 TFEU rights, this underlying conception of Union citizenship has ultimately found expression in Directive 2004/38/EU which clearly reflects a gradualist approach towards the acquisition of rights of the mobile Union citizen in the host Member State, leading ultimately to the quasi-full membership under the status of permanent resident.

\section{b) Interpreting Directive 2004/38/EC}

In asserting and operationalising the rights found in primary legislation, the Court has performed a classic duty of a constitutional court, as outlined by Níc Shuibhne above. It has also informed the further development of Union citizenship. However, as is noted above, the legislature is given a key role to play in articulating and developing the status of Union citizenship. In its engagement with the Directive, the Court has respected the role of the legislature, both in the normative choices it made with respect to specific provisions but also in the broader contribution it has made and the vision of Union citizenship the Directive reflects.

The debate on the interpretation of the Directive, particularly after the Dano line of caselaw, is often focused on an activist interpretation of secondary legislation or a more deferential, literalist approach. ${ }^{59}$ From this perspective, we witness inconsistencies in the approach of the Court either across

57 Coutts, S. (2020). The Shifting Geometry of Union Citizenship: A Supranational Status from Transnational Rights. Cambridge Yearbook of European Legal Studies 21 pp 318-341.

$5^{8}$ For a particularly progressive and expansive vision of the potential of Union citizenship see Kochenov, D. (2017). On Tiles and Pillars: EU Citizenship as the Federal Denominator. In: Kochenov, ed.,EUCitizenship and Federalism: The Role of Rights. Cambridge: Cambridge University Press.

59 See Van den Brink, M. (2019). Justice, Legitimacy and the Authority of Legislation within the European Union, cit. 
time, or even across the Directive itself. As noted by van den Brink, a literal approach towards interpretation is taken in social assistance judgments, such as Dano and Alimanovic, at the same time as a purposive or more active approach is taken in the area of public security, such as in PI and Onukwere. ${ }^{60}$ However, while seen from the point of view of interpretative approach there is a degree of inconsistency in the Court's approach, what is consistent in the interpretation of the Court is its adherence to the concept of social integration as the guiding principle of the Directive and of Union citizenship more broadly. What we have witnessed is an engagement with the text of the Directive and the choices made in that legislation and an appreciation of the constitutionally allocated role of the legislature in this area.

In the field of social assistance, we have certainly witnessed a shift or at least a marked development in the jurisprudence of the Court. ${ }^{61}$ This has been characterised by a more deferential approach to the legislature, with the Court now relying primarily on secondary rather than primary law provisions, ${ }^{62}$ a fact that is also reflected in a more textualist approach to the interpretation of that Directive. ${ }^{63}$ However, it is submitted that there remains an purposive dimension to the Court's approach. The underlying philosophy of social integration still aminates the Court's approach towards transnational citizenship matters, the difference is that it is more deferential to the legislature's choices regarding how that integration is to be measured; behind a literal approach lies a teleological backdrop. As noted by Jesse and Carter, Förster (which can be instructively contrasted with Bidar) is an early indication of this approach. ${ }^{64}$ In Förster the Court, applying its traditional approach towards equal treatment based on a degree of social integration, found that five years residence period was appropriate to ensure that an individual had a certain connection with the society of the host member state, in this case the

6o Ibid at 305. These judgments are not uncontested and have been criticising not simply for introducing an exclusionary and discriminatory dynamic into the operation of Union citizenship but also for contradicting the spirit of the Directive itself. See for example Spaventa, E. (2017). Earned Citizenship: Understanding Union Citizenship through its Scope, cit., and Kostakopoulou, D. (2014). When EU Citizens become Foreigners. European Law Jounal 20 (4), pp. 447-463.

61 For a contrary view see Davies, G. 'Has the Court changed, or have the cases? The deservingness of litigants as an element in Court of Justice citizenship adjudication' (2018) Journal of European Public Policy 25 (10), pp.1442-1460.

62 See Muir in this volume.

63 See Jesse and Carter in this volume and Van den Brink, M. (2019). Justice, Legitimacy and the Authority of Legislation within the European Union, cit.

64 Jesse and Carter in this volume at *. 
Netherlands. It was explicitly inspired in this approach by the five-year period contained in the Directive in order to acquire permanent residence, a status which in turn guarantees unconditional equal treatment. ${ }^{65}$ This is not a simple application of a black letter rule found in the legislation but reflects for the Court an aspect of the underlying logic of integration that animates the Directive as a whole. The five-year rule contained in the Directive is used as a proxy for the degree of integration an individual has achieved in the society of the host Member State.

The line of cases starting with Dano can certainly be understood as a restrictive turn in the Court's jurisprudence, ${ }^{66}$ protecting the interests of states vis-à-vis mobile Union citizens in a period of hostility to migration. In the abandonment of the individualised proportionality test they also provide more certainty to individuals and especially to administrations. ${ }^{67}$ Finally, they are also a case of a more faithful and deferential approach to the text of the Directive itself, abandoning references to primary law and the need to assess the proportionality not only of the secondary law but of its application in individual cases that began in Baumbast. ${ }^{68}$ These cases represent all of these things. However, in them the Court does not abandon the social integration approach but instead defers to the legislative choices regarding the criteria for assessing whether or not that integration is achieved. An early indication of this approach can be found in Dias where the conditions contained in Article 7 of the Directive were said to represent 'qualitative elements relating to the level of integration in the host Member State' ${ }^{69}$ Understood against this characterisation of the Article 7 conditions it is evident that Dano, in making equal treatment contingent on residence in compliance with the conditions found in Article 7 of the Directive, was in effect making access to social assistance contingent on the level of integration in the host Member State. Only now, the criteria for the integration of the individual were those found in the Directive itself. Echoing this, in Alimanovic, the Court found that an individual assessment was unnecessary as 'Directive 2004/38, establishing a gradual system ... itself takes into consideration various factors characterising the individual of

65 Court of Justice, judgment of 18 November 20o8, case C-158/o7, Jacqueline Förster v IB Groep, para. 55 .

66 See generally the contributions in Thym, D., ed. (2017). Questioning EU Citizenship:Judges and the Limits of Free Movement and Solidarity in the EU. Oxford/Portland: Hart Publishing.

67 See Jesse and Carter in this volume.

68 Baumbast and R, cit.

69 Court of Justice, judgment of 21 July 2011, case C-325/o9, Secretary of State for the Home Department v. Maria Dias, para. 64 . 
each applicant for social assistance and in particular, the duration of the exercise of any economic activity. ${ }^{70}$

That the Court is concerned with the underlying philosophy of the Directive rather than a close and literal approach towards its interpretation is evidenced by its approach in public security matters, which as van den Brink notes were characterised by an interpretative approach which appeared to contradict the literal meaning of the Directives provisions. In Tsakouridis ${ }^{71}$ and $P I,{ }^{72}$ the Court gave an interpretation to the term 'public security' which was broader than the term is normally understood and appeared to contradict the distinction the legislature wished to establish between public policy and public security. ${ }^{73}$ It is arguable that what lay behind this determination was not a security-orientated Court, although this is certainly a possibility, but also an understanding of the relationship between rights acquisition, appropriate behaviour and integration. As is articulated in the Opinion of AG Bot in PI, under a scheme which is characterised by a gradual acquisition of rights on the basis of social integration, it is difficult to rationalize a heightened level of protection from expulsion for those individuals who through their behaviour have demonstrated a distinct absence of integration with the society of the host Member State. ${ }^{74}$ While the Court did not follow the Advocate General in denying PI the protection offered by Article 28(3) of the Directive, in its interpretation of the concept of public security it achieved a similar result, radically diminishing the importance of this heightened protection for those who have committed particularly serious crimes.

Similarly, in cases relating to imprisonment and the acquisition of this heightened protection under Article 28(3) Directive 2004/38, the Court has insisted on the link with the social integration of the individual. Heightened protection is acquired after ten years residence in the host Member State.

70 Court of Justice, judgment of 15 September 2015, case C-67/14, Jobcenter Berlin Neukölln v. Nazifa Alimanovic and Others, para. 6o.

71 Court of Justice, judgment of 23 November 2010, case C-145/o9, Land Baden-Wurttemberg $v$ Panagiotis Tsakouridis.

72 Court of Justice, judgment of 22 May 2012, case C-348/og, PI v. Oberburgermeisterin der Stadt Remscheid.

73 See Kostakopoulou D., and Ferreira, N. (2014) Testing Liberal Norms: The Public Policy and Public Security Derogations and the Cracks in European Union Citizenship. Columbia Journal of European Law 20 (3), pp. 167-192 and Azoulai, L., and Coutts, S. (2013). Restricting Union Citizens' Residence Rights on Grounds of Public Security. Common Market Law Review 50 (2), pp. 553-570.

74 Opinion of AG Bot delivered on 6 March 2012, case C-348/og, PIv. Oberburgermeisterin der Stadt Remscheid paras. 53-62. 
However, first in Onukwere $e^{75}$ and later confirmed (and nuanced) in B and Vomero ${ }^{76}$ these ten years can be broken by the conviction and imprisonment of the individual. In order to determine if an individual benefits from the heightened protection an assessment of the interrogative links he or she enjoys with the society of the host Member State should be carried out, an assessment that should take into account various factors, including the nature of the offence and conduct while in prison. ${ }^{77}$ The contrast with the social assistance cases is marked, not only in reading additional conditions into a Directive which contains a simple ten-year rule, but also in introducing a standard based test and the associated administrative uncertainty, which the new approach in Dano is intended to remove. What links both sets of cases however is an overall faithfulness to the underlying conception of Union citizenship as a status of social integration, a conception reflected in the Directive.

\section{c) Applying the Directive by Analogy}

A further aspect of the Court's engagement with Directive 2004/38/EC has been the use of the Directive in areas not covered by the Directive itself, extending in effect the choices inherent in Directive 2004/38/EC to novel situations. This both underlines the central importance of the Directive and the vision of Union citizenship it reflects and ensures a greater coherence across Union citizenship law.

Firstly, the conditions under Article 7 of the Directive have been used by the Court of Justice in situations of family reunification and circular migration. Here an individual travels to another Member State, enjoys a family life there, and seeks to maintain that family life upon return to his or her home Member State. Such situations, dealing with the situation of Union citizens in their home Member State, are not governed by Directive 2004/38/EC, and yet the Court of Justice has relied on the conditions in Article 7 as criteria to ensure than an individual has enjoyed 'genuine residence' in the second Member State and that family life is 'created or strengthened in that Member State' as a result. ${ }^{78}$ Only under these conditions can an individual then return to his or

75 Court of Justice, judgment of 16 January 2014, case C-378/12, Nnamdi Onuekwere v. Secretary of State for the Home Department.

$7_{6}$ Court of Justice, judgment of 17 April 2018, joined cases C-316/16 and C-424/16, Bv. Land Baden-Württemberg and Secretary of State for the Home Department $v$. Vomero.

77 Ibid, paras. $70-75$.

78 See Court of Justice, judgment of 12 March 2014, case C-456/12, Ov. Ministervoor Immigratie, Integratie en Asiel and Minister voor Immigratie, Integratie en Asiel v. B, para. $5^{1}$ and Court of justice, judgment of 5 June 2018, case C-673/16, Coman and ors v. Inspectoratul General pentru Imigrări and ors, para. 24. 
her Member State. Furthermore, the provisions of the Directive are to apply by analogy to govern the family reunification right upon return to the home Member State. ${ }^{79}$ This logic and a similar use of the Directive was also extended to dual nationals Union citizens in Lounes, ${ }^{80}$ at least where nationality of the Member State of residence was acquired on foot of previous free movement. ${ }^{81}$

The use of the rules contained in the Directive has also occurred in the field of expulsion matters where an individual who enjoys a right to reside under Article 20 TFEU. In Rendon-Marin ${ }^{82}$ and in CS, ${ }^{83}$ the Court of Justice found that removal of the parent of a Union citizen would lead to the deprivation of the genuine enjoyment of the Union citizenship rights of the minor child. ${ }^{84} \mathrm{~A}$ right of residence for those parents would therefore need to be provided. However, it also found that that right could be restricted for reasons of public policy and public security. Without explicitly mentioning Directive 2004/38, in outlining the conditions under which such as assessment should take place, the Court drew heavily on its jurisprudence developed in the context of mobile Union citizens and especially in its interpretation of analogous provisions under Directive 2004/38/EC. ${ }^{85}$ While the possibility of expulsion in Article 20 TFEU cases is not unproblematic, in light of the removal of the Union citizen child from the territory of the Union as a whole, the approach adopted by the Court at least has the merit of ensuring a degree of coherence across Union citizenship law, principally based on rules developed on the basis of the Directive.

\section{Conclusion}

The early years of Union citizenship were marked by a certain tension between the Court and the legislature. Grzelczyk, Trojani, Baumbast \& $R$ and Bidar all appeared to at least limit or modify conditions contained in the secondary law

$79 O \& B$, cit., para. 50 and Coman, cit., para. 24.

8o For a discussion see De Groot, D. (2018). Free Movement of Dual EU Citizens. European Papers 3 (3), pp. 1075-1113, who points out the complications created by this judgment for dual nationals of various types and the need for it to be reconciled with $O \& B$ and the situation of returnees in particular.

81 Court of Justice, judgment of 14 November 2017, case C-165/16, Toufik Lounes v. Secretary of State for the Home Department.

82 Court of Justice, judgment of 13 September 2016, case C-165/14, Alfredo Rendón Marín v. Administración del Estado.

83 Court of Justice, judgment of 13 September 2016, case C-304/14, Secretary of State for the Home Department v. CS.

84 Ibid, para. 32 and Rendón Marín, cit., para. 78.

85 See especially CS, cit., paras. 39-49. 
in force at the time, namely the residence Directives. Kay Hailbronner was particularly critical at the time, seeing a clear contradiction between the text of the Directives and the position of the Court of Justice in extending welfare assistance to individuals who failed to fulfil the relevant conditions. ${ }^{86}$ What is apparent is that in these judgments, the Court of Justice was performing its allocated constitutional role, identifying and making meaningful the primary law nature of the status of Union citizenship and the rights that accompany it. Dougan at the time also noted the constitutional significance of the judgments and their treatment of secondary legislation, insisting on a proportionality assessment on the actions of Member States even when they were acting within the strict text of the Directives; thereby imposing indirectly subjecting the secondary legislation of the Union to constraints. ${ }^{87}$

The adoption of Directive 2004/38/EC represented a clear turning point in the approach of the Court. As put by Níc Shuibhne " $[t]$ he negotiation and adoption of this measure restored a sense of institutional mutuality, reviving the legislative-judicial interplay that characterised the regulation of personal free movement in earlier times. ${ }^{\prime 88}$ The Directive respected the Court's earlier interventions by codifying its jurisprudence and developing its underlying understanding of Union citizenship as a status of social integration. The underlying concept of Union citizenship as a status of social integration, establishing various rights and responsibilities between the mobile Union citizen and the host Member State is its basic operating principle. This is reflected not only in the gradualist scheme underpinning the Directive and the creation of various categories of citizens but also in the main innovation of the Directive, namely the status of permanent residence. The Directive therefore occupies an important place in Union citizenship law. This is a function of its codifying and comprehensive character, offering not only a coherent set of detailed rules but also an underlying philosophy of the status. It marks a distinct legislative intervention in the field, seeking to contribute to the constitutional construction of Union citizenship and give direction to its development. It is also a function of the unusual position of secondary legislation and hence the legislature in the constitutional framework established by Articles 20 and $21 \mathrm{TFEU}$, which acknowledges an ability to establish limits and conditions to constitutional

86 See Hailbronner, K. (2005). Union Citizenship and Access to Social Benefits. Common Market Law Review 42 (5), pp. 1245-1267.

87 Dougan, M. (2006). The Constitutional Dimension to the case law on Union Citizenship, cit.

88 Níc Shuibhne, N. (2012). The Third Age of EU Citizenship. In: Syrpis, ed., The Juriciary, the Legislature and the EU Internal Market. Cambridge: Cambridge University Press, pp. 333-334. 
rights. The legislature therefore enjoys a therefore a constitutional mandate to shape the institution.

Perhaps mindful of this position, the Court in its engagement with the Directive has been largely respectful of its limits but more importantly has engaged with the underlying philosophy of the Directive. The relationship between the mobile Union citizen and host Member States based on rights and increasingly responsibilities and operating before a backdrop of social integration is one taken seriously by the Court. This helps explain the different approaches to the interpretation of the Directive we have witnessed in the latest, so-called restrictive, phase of Union citizenship. Social assistance and public security judgments display different interpretative techniques. Under normal circumstances this would indicate a variable attitude towards the position of the legislature. However, considered against the backdrop of the particular vision of Union citizenship embodied in the Directive, the divergent approaches of the Court are more understandable. In social assistance matters the Court has not so much abandoned its prior commitment to protecting a status of social integration but instead has deferred to the legislature regarding the criteria according to which such integration should be measured. This does entail a modified position for individuals, imposing requirements of economic activity and removing individual assessments. However, it is not inconsistent with the broader vision of Union citizenship pioneered by the Court of Justice in its earlier caselaw and developed further by the legislature. Similarly, its more creative approach to its interpretation of public security and heightened protection does go beyond the literal meaning of the relevant provisions of the Directive. However, its reading is informed by the centrality of social integration, only now complemented with a certain obligations of good behaviour imposed on the individual. Finally, the central position of the Directive in the operation of Union citizenship law is underlined by its use by the Court in situations not covered by the Directive, principally family reunification in situations of circular migration.

To date, Union citizenship has operated almost exclusively on a transnational plane, allowing individuals to assert rights vis-à-vis other Member States. In achieving this it has developed a status of transnational social integration. Both the Court, in its initial judgments and its deployment of powerful concepts of equal treatment and proportionality, and the legislature in providing a legislative framework which progressively awards rights to individual Union citizens based on a variety of criteria of time, residence and economic criteria, have contributed to this construction. More recently, the Court has begun to develop Union citizenship in another direction under Article 20 TFEU. In doing so it is playing its role as a constitutional court, emphasising the 
constitutional nature of this status, developing its key principles and ensuring that protections offered by that status are enjoyed by individuals. We are perhaps at the beginning of a new age of Union citizenship, where its impact will be felt across a wider field of Union law. ${ }^{89}$ What role the legislature will play is as yet uncertain. But its intervention will be crucial, not simply in providing legal certainty but in giving shape and direction to this status. The roles played by the Court and the legislature in Union citizenship have to date been largely complementary and symbiotic, characterised by mutual engagement and coconstructing a meaningful status for mobile Union citizens. It is to be hoped that a similar constructive approach will characterise the future development of this key institution for the Union.

89 See Kochenov, D. (2017). On Tiles and Pillars: EU Citizenship as the Federal Denominator, cit., and Sarmiento, D., and Sharpston, E. (2017). European Citizenship and its New Union: Time to Move On? In: Kochenov, ed., EU Citizenship and Federalism: The Role of Rights, cit. 